\title{
University Graduates: Potential Advantage or Trouble of the Czech Labor Market?
}

\author{
Marcela GÖTTLICHOVÁ \\ Tomas Bata University in Zlin, Štefánikova 2431, 76001 Zlin, Czech Republic \\ gottlichova@utb.cz
}

Received date:1 October 2019; Accepted date: 26 January 2020; Published date: 11 June 2020

Academic Editor: Frantisek Stellner

Copyright @ 2020. Marcela GÖTTLICHOVÁ. Distributed under Creative Commons Attribution 4.0 International CC-BY 4.0

\begin{abstract}
The objectives of the study, as presented in the introductory part, are to lay out the employment specifics in the Czech Republic in continuity with the level of higher education as perceived from the perspective of the educational structure oriented at university graduates; still the riskiest group in the labor market. Thus, what remains the center of attention is the necessity of professional preparation of university students in terms of key competencies in continuity with sufficient experience to ensure their success in the labor market. The primary objective of this study is also aimed at addressing the current situation. The Introduction points at the current level of the Czech labor market with the focus on regional specification in connection with the Czech state tertiary education, and this part is followed by introducing possible solutions to the current situation, based on the quantitative data research conducted over three years by students of the Faculty of Multimedia Communications at Tomas Bata University in Zlin on one side. On the other hand, the survey also included nonprofit organizations with one common goal; the development of key competencies in continuity with the requirements of nonprofit entities in the output stemming from experience, reflecting within the academia and the nonprofit sector to support the development and possible future career orientation in marketing communication activities.
\end{abstract}

Keywords: Labor market, employment and unemployment, higher education, key competencies. 


\section{Introduction}

Despite the international comparison, the Czech Republic (CR) had the lowest unemployment rate in the entire European Union according to the latest available EUROSTAT data (June 2019), the employment of young people in the labor market has been becoming more and more critical in all European countries. The fact that it is the level of education that is becoming a decisive factor for the employment of the young generation entering the labor market has been strongly proven. In the form of a constant conflict between demand and supply, this reflects an ongoing confrontation between the structure of job posts and their geographical locations on one hand. On the other hand, it is the comparison between the offers of graduates at various education levels and the necessary professional qualifications. A significant position belongs to university graduates. Although the unemployment rate of university graduates in the Czech Republic shows a decreasing tendency, it is still one of the riskiest groups in the labor market. The primary reason for this is the lack of preparedness of university students in terms of inherent key competencies in continuity with sufficient practical experience, which would lead to the desired achievement in the domestic labor market. Thus, the fundamental question is what steps must be taken in the education system so that graduates can represent significant players in the labor market in the Czech Republic? The aim of this paper is also to outline the path leading to enhance the employability of university graduates in the labor market.

\section{Current State Analysis}

\section{Labor Market}

"The labor market is a susceptible area of the economic life", because "the subject of the market is a person with his specific characteristics and requirements" (Jírová, In: Spěváček et al., 2002, p. 247). The forms of labor market relations are based on and correspond to the structure of participants in specific activities where the workforce is usually the main actor, defined as the sum of employed and unemployed persons within a particular economy (e.g., a country) offering their abilities, experiences, and skills. "Certain self-regulation based on respect for certain principles, such as respect for the law, the sense of social solidarity, ecological awareness, understanding, humanity and tolerance among members of the society, etc., is also necessary for the perfect functioning of the market (Jurečka et al., 2010, p. 334)."

\section{Risks of Entering the Labor Market}

Significant risks of entering the labor market are increasingly difficult barriers to address in continuity with low level of education that does not meet the current technological requirements and are reflected in the increasing mismatch between job supply and education/qualification (qualification gap), which, in turn, leads to more obvious misplacement of unskilled or under skilled labor in the labor market. "Those people that are usually unemployed have no previous job experience, completed only primary education, and are not willing to travel to work (Novák et al., 2016, p. 13)." A present characteristic feature is seen in the ever-increasing preference of the so-called knowledge workers, whose basic capital and at the same time the 'working tool' is the already mentioned knowledge, skills and abilities representing a significant source of their employability; the so-called dimension of human (knowledge, skills and experience) and social (social interaction and communication) capital (intellectual capital), which is the crucial precondition for one's ability to identify and realize his career opportunities (Horáková, Horák, 2013). In addition to education, work experience and qualifications significantly contribute to strengthening the labor market position (Kuchař, 2007). 


\section{The Significance of Education as an Economic Variable}

The importance of education in the context of theory over the past 60-70 years has been increasingly discussed in the economy from the perspective of economic variables, not of the fundamental social need. Education was accepted as an investment that was supposed to capitalize on higher profits for the future, both for individuals in the form of higher wages, and for companies in increasing labor productivity, and for the society in the technological progress and higher consumption. Human capital has thus become a significant and decisive factor in wealth creation in developed countries. As Balcar puts it, in conjunction with the historical insight, "at all times within the human society, the individual components of human capital, although their importance has changed with changes in the institutional conditions, have been considered not only for individuals but also for the development of the society as a whole" (2006, p. 92).

\section{The European Union}

"The financial and subsequent economic crisis caused a sharp deterioration in labor market conditions which particularly affected the youth group" (Hedvičáková, 2018 , p. 3,357), representing a risk group in the labor market. This is linked to the development of education in continuity with the level of education attained, which is reflected in the possibility of the young generation to find employment in the labor market, which remains at the forefront of the European Union (EU) as a whole. This is confirmed by the primary objectives of the Education and Training 2020 Strategy (ET 2020), which draws attention primarily to both "improving the quality and effectiveness of education and training" and "improving creativity and innovation, including entrepreneurship, at all levels of education and training" (ET 2020, 2019). Also, the Europe 2020 Strategy, building on the so-called Lisbon Strategy, targets to achieve sustainable EU economic growth by investing more effectively in education, research, development, and innovation, and developing a competitive industry (Europe $2020,2019)$. One of the primary objectives of the strategy of reaching $40 \%$ of $30-34$ year-olds in the EU with tertiary education completed by 2020 , confirms setting the right path. Since 2020 (23.6\%), when the series began, there has been a steady increase. And, as recent results have shown, in 2018 the threshold was even exceeded (40.7\%), with women at the forefront of success $(2002 / 24.5 \% \times 2018 / 45.8 \%)$ versus men $(2002 / 22 \% \times 2018 / 35.7 \%)$ who have not yet exceeded the threshold (EUROSTAT/72, 2019).

\section{Employment Rates of Recent Graduates}

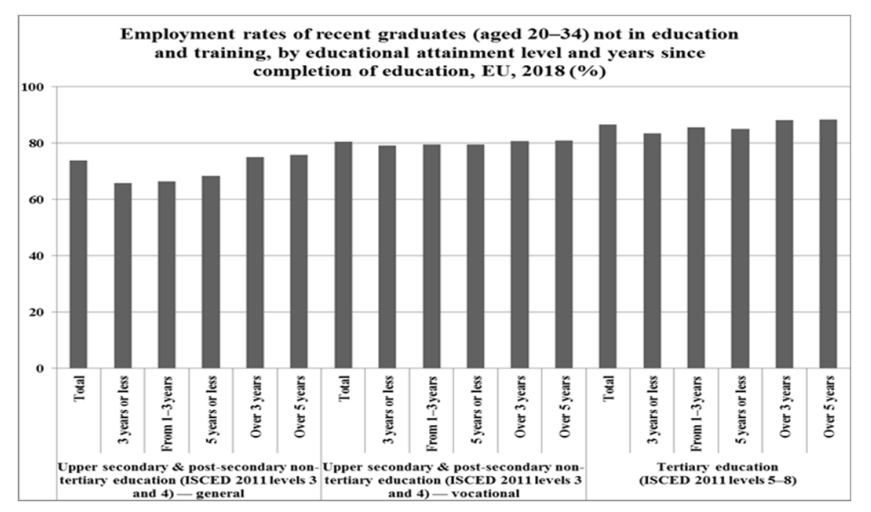

Fig. 1: Employment rates of recent graduates (aged 20-34) by educational attainment level and years since completion of school, EU, 2018 (\%)

(Source: Eurostat/C3 - online data code: edat_lfse_24)

Marcela GÖTTLICHOVÁ (2020), Journal of Eastern Europe Research in Business and Economics, DOI: $10.5171 / 2020.543568$ 
As already mentioned, one of the primary ways to tackle the problem of youth unemployment is the need to emphasize a higher level of human capital input, while consistently supporting programs to prevent early school-leavers. It is primarily the acquisition of tertiary education level that significantly contributes not only to improving the employment prospects of young people, but also to an increasing tendency to get their first job faster (total/86.5\%; 3 years or less/83.4\%; from 1-3 years/85.5\%; 5 years or less/85.0\%; over 3 years $/ 88.2 \%$; over 5 years $/ 88.4 \%$ ) than those with lower level of education (Figure1) (Eurostat/C3, 2019).

\section{Disparities by Educational Attainment Level}

The fact that the level of educational attainment plays the key role in the employment of graduates in the labor market is confirmed by the following figure (Figure 2). While young people have faced increasing challenges in the transition from education to workforce in recent years, as shown by the results, in 2018 the employment rate of recent tertiary graduates (1-3 years after university graduation) was over $90.0 \%$ in Austria (90.1\%), Belgium (90.3\%), Lithuania (90.4\%), Latvia (91.3\%), Hungary (91.5\%), Czech Republic (91.5\%), Sweden (92.5\%), Luxembourg (94.0\%), Germany (94.3\%), the Netherlands (94.8\%) and Malta $(96.7 \%)$. The reflection of the financial and economic crisis was most pronounced in Greece (59.0\%) and Italy (62.8\%) (Eurostat/D52,2019).

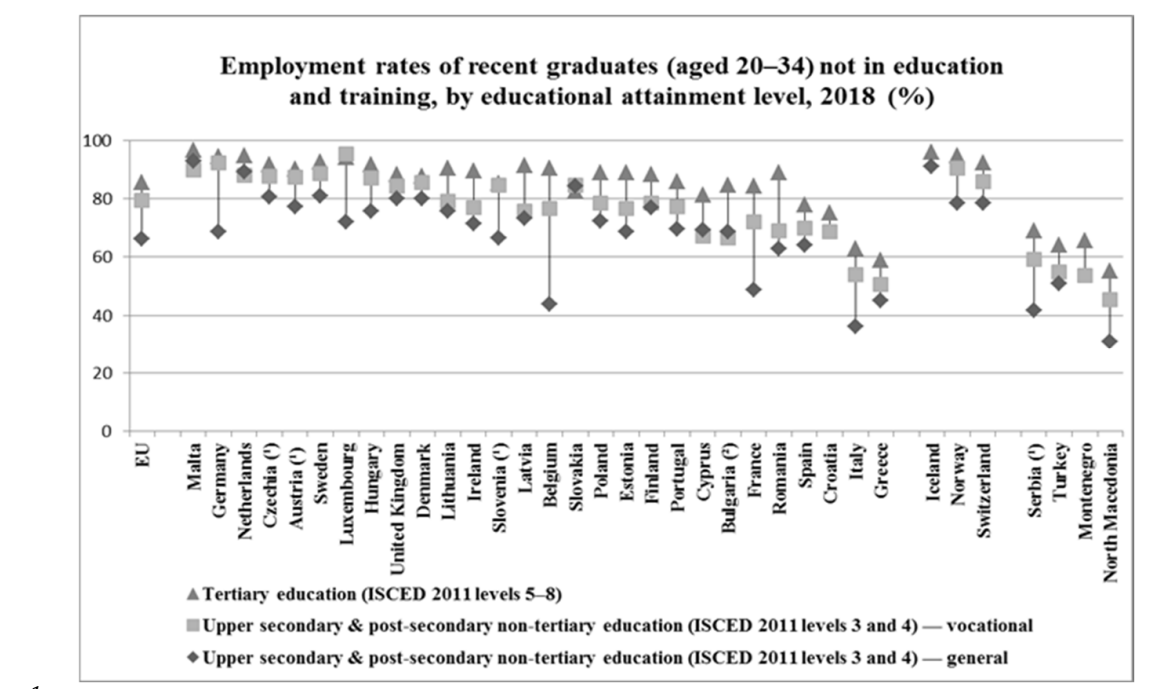

$\left({ }^{1}\right)$ Upper secondary \& post-secondary non-tertiary education-general: low reliability

Fig. 2: Employment rates of recent graduates (aged 20-34) by educational attainment level, EU, 2018 (\%) (Source: EurostatúD52 - online data code: edat_lfse_24)

A more detailed specification of the values (Figure 2) shows that in 2018 the Czech Republic outstripped the EU (CR/89.6\% $\times$ $\mathrm{EU} / 81.6 \%$ ) in the employment of graduates of upper secondary, post-secondary nontertiary and tertiary education (ISCED 2011, levels 3-8); namely: ISCED 2011, levels 3 and 4 - general $=\mathrm{CR} / 80.6 \% \times \mathrm{EU} / 66.3 \%$; ISCED 2011, levels 3 and 4 - vocational =
CR/87.7\% × EU/79.5\%; ISCED 2011, levels $5-8$ tertiary education $=\mathrm{CR} / 91.5 \% \times$ EU/85.5\% (Eurostat/D52, 2019).

\section{The Czech Labor Market Specifics}

One of the most important specifics of the labor market in the Czech Republic is the low mobility and flexibility of the workforce, 
presenting the legacy of the previous regime and the so-called false miracle of low unemployment characteristic in the first half of the 1990s. In particular, the regional character of the labor market is based on different geographical, demographic, historical, social and especially economic conditions in individual regions, clearly affecting the level of employment, reflected in imbalances caused by labor surplus or deficiency in some professions or sectors. Related to this, is "a significant increase in regional disparities in youth unemployment rates" (Gontkovičová et al., 2014, p. 682), which can also be seen across the EU.

\section{Employment and the Education Level in the Czech Republic}

The sectoral and professional structure of employment is closely linked to the educational structure of the population. The most significant increase in jobs in 2018 can be seen in those persons who work and have graduated from a tertiary education institution (by 34,3 thousand), with the number having increased to 1317,3 thousand, i.e., by $2.7 \%$ ( $\times 2017 / 1283,0$ thousand). A characteristic feature of the representation of university students in the labor market is a decreasing tendency in continuity with increasing age, except for the 65+ age group, as evidenced by the highest representation in the younger age groups of productive age where the highest number of university graduates is aged 25$39(32.1 \%)$. In contrast, the highest proportion of $32.8 \%$ is being observed in the age group 25-29 years of age and 33.7\% in the age group 30-34 year-olds. These age groups accounting for (A) $13.6 \%$ and (B) $14.5 \%$ of total employment. In terms of educational structure and employment, there are also differences at the regional level. Within the 15 regions of the Czech Republic, as seen from the perspective of the employment of university students, the capital city of Prague (45.6\%) is most prominent, the Region of Ústí nad Labem $(14.5 \%)$ is the lowest, and the Zlin region ranks as the seventh (20.7\%) (CSO-LM, 2019).

\section{The Zlin Region and Unemployment}

In terms of unemployment in the Zlin Region, there has been a significant decline since 2010 . While in 2010, the total number of unemployed was 24,5 thousand, in the age group (I) of 20-24 the number of unemployed was 3,2 thousand and in the target group (II) 25-29 years it was 4,4 thousand of unemployed, in 2017 the number of unemployed decreased to the total of 10,5 thousand, of which in (I) to 2,5 thousand, and in (II) to 1,2 thousand of unemployed, in 2018 there was a further decrease to the total of 5,2 thousand, of which in (I) to 0,7 thousand, and in (II) to 0,9 thousand of unemployed. As the values of the following table (Table 1) show, in terms of education attained in continuity with employability in the labor market, the continuously decreasing number of university graduates in the Zlin Region (ZR) in terms of unemployment becomes an important indicator (CZSO-ZR, 2019).

Table 1: Education of the unemployed in the ZR (in thousands) (Source: CZSO-ZR, 2019)

\begin{tabular}{|l|c|c|c|}
\hline Unemployed & $\mathbf{2 0 1 0}$ & $\mathbf{2 0 1 7}$ & $\mathbf{2 0 1 8}$ \\
\hline Total: & 24,5 & 10,5 & 5,2 \\
\hline of which by education level: & & & \\
\hline Primary and no education & 4,5 & 1,9 & 0,6 \\
\hline $\begin{array}{l}\text { Secondary education without the Maturita } \\
\text { exam }\end{array}$ & 11,0 & 4,6 & 2,2 \\
\hline Secondary education with the Maturita exam & 6,8 & 2,7 & 1,9 \\
\hline Tertiary - university type & 2,2 & 1,3 & 0,5 \\
\hline
\end{tabular}

Marcela GÖTTLICHOVÁ (2020), Journal of Eastern Europe Research in Business and Economics, DOI: $10.5171 / 2020.543568$ 


\section{Tertiary Education in the CR: Universities - students and graduates}

Significant changes in the Czech higher education occurred primarily after the socalled Velvet Revolution (1989), which enabled not only the rapid development of higher education institutions, but consequently also in the area of private higher education, when the first three private universities were opened in 1990 and with the vast increase in 2007 with the number of 46 universities. However, since 2014 , there is a downward tendency at 36 universities (2014/44, 2015/43, 2016/40, $2017 / 38,2018 / 36)$. In the field of public universities since 2006, the situation stabilized at 26 universities (2005, $2004 / 25$; 2003-2001/24; 2000/23; ...) in
2004 when the number of state universities decreased from four to the current two (Police Academy of the Czech Republic in Prague; and University of Defense) (MIMEYS, 2019).

In addition to the decrease in the total number of universities, the number of students has also been decreasing, with 2010 as a milestone (public universities/339,356; private universities/57,324) $\times 2018$ (public universities/261,796; private universities $/ 28,726$ ) in terms of the quality of students, as opposed to the preferred quantity in the longer 'post-revolutionary' period, as compared to the more extended post-revolution period with the preference of quantity (Table 2) (UG-MEYS, 2019).

Table 2: University graduates in the CR in types of study programs by age

\begin{tabular}{|c|c|c|c|c|c|c|}
\hline \multirow[b]{2}{*}{ Founder/age } & \multicolumn{2}{|c|}{ Total } & \multicolumn{4}{|c|}{ Type of study program } \\
\hline & & & $\begin{array}{c}\text { Bachelor' } \\
\text { s } \\
\end{array}$ & Master's & $\begin{array}{l}\text { Follow-up } \\
\text { Master's }\end{array}$ & Doctoral \\
\hline & total & $\begin{array}{c}\text { out of } \\
\text { which } \\
\text { females }\end{array}$ & total & Total & total & Total \\
\hline \multicolumn{7}{|l|}{$\begin{array}{l}\text { Total number } \\
\text { of universities: }\end{array}$} \\
\hline 2010 & 81,331 & 48,994 & 46,008 & 8,735 & 24,710 & 2,000 \\
\hline 2018 & 59,978 & 36,160 & 30,690 & 3,642 & 23,738 & 1,691 \\
\hline \multicolumn{7}{|l|}{ Out of which: } \\
\hline $\begin{array}{l}\text { 20-24-year- } \\
\text { olds }\end{array}$ & 22,385 & 14,051 & 19,058 & 499 & 2,837 & - \\
\hline $\begin{array}{l}\text { 25-29-year- } \\
\text { olds }\end{array}$ & 26,701 & 15,561 & 6,841 & 2,825 & 16,797 & 276 \\
\hline $\begin{array}{l}\text { 30-34-year- } \\
\text { olds }\end{array}$ & 3,981 & 2,054 & 1,286 & 146 & 1,440 & 1,111 \\
\hline
\end{tabular}

The situation according to the Association of Student Registries (SIMS) as of January 21, 2019

(Source: UG-MEYS, 2019)

Marcela GÖTTLICHOVÁ (2020), Journal of Eastern Europe Research in Business and Economics, 


\section{Methodology}

\section{Problem Formulation}

While these surveys show a significantly improving situation for youth employment and unemployment, young people, especially those graduates who are entering the labor market to apply for their first jobs; are still considerably disadvantaged in the competition with other job seekers. As mentioned several times, it can even be the most vulnerable group in the labor market. The primary cause of this situation is still the frequent absence of work experience and essential work habits, which are related to the absence of necessary working contacts, which can help graduates facilitate difficult orientation in the labor market. An eventual initial failure for graduates is entering the labor market then it may harm their future professional life.

Thus, it becomes necessary for universities to focus their attention on the development of key competencies, primarily those that, from the perspective of employers, will lead to increased employability of university graduates. However, it is not only the commercial sector that plays a vital role in the employment of graduates in the labor market. There is also a great potential in the non-commercial sector, in particular, non-governmental non-profit organizations, which, by realizing their mission, make a significant contribution to addressing the region's issues - and as shown in Table 3 , their numbers continue to increase.

Table 3: The statistics of the number of non-profit organizations in 2017-2018

\begin{tabular}{|c|c|c|c|c|c|c|c|}
\hline & A & FF & EI & RS & CIO & CA & B \\
\hline 2017 & 93,651 & 515 & 1,670 & 762 & 2,744 & 4,171 & 26,414 \\
\hline 2018 & 96,722 & 548 & 1,887 & 911 & 2,712 & 4,143 & 27,291 \\
\hline
\end{tabular}

Associations/A, Foundations Funds/FF, Endowment Institutes/EI, Registered Societies/RS, Charitable Incorporated Organization/CIO, Church Associations/CA, Branch/B

(Source: CZSO-NGOs, 2019)

\section{Problem Solution}

As for the education system of the Czech Republic, the fundamental solution is to place constant emphasis on improving the quality of higher education. Among the important tasks are, the emphasis on the quality of educational activities reflected in the organization in terms of professional events, to share good practice and support innovation in teaching higher educationoriented with the quality of studies primarily in the first years of bachelor's programs by strengthening the involvement of employers in educational activities and popularizing examples of good practice. Other crucial steps also include the need to "take regionally relevant topics and challenges in project teaching and assigning theses into account, and promote the use of student project results in real-life practices, and their implementation can be a regular part of teaching to contribute to solving local problems. Also there is a need to support and encourage innovative student activities in the form of incubators, startups, spin-offs, and other forms of entrepreneurship skills" (Long-term Intention 2020-MEYS, 2019).

\section{Objectives and Methodology}

In relation to the primary tasks of the "Longterm Intention..." aiming at linking the theory and practice with a focus on enhancing project education supported by regional topics, since 2012, the Department of Marketing Communications at the Faculty of Multimedia Communications of Tomas Bata University in Zlin, within the project called "the Cooperation of higher education, public administration, business and nonprofit sector for socio-economic development of the region", has been cooperating with 
representatives of the non-profit sector (the Association of non-governmental non-profit organizations), the Zlin Region, the Town of Zlin, the Regional Chamber of Commerce and the Labor Office, and has been dealing with the problems of the region, focusing primarily on the cooperation between the academia and the non-profit sector (Göttlichová, 2012). Every year, the attention is paid to research activities directed to both non-governmental organizations (NGOs) of the Zlin Region, as well as to the students of the Institute.

In 2019, as well as in 2017 and 2018, the attention was again directed not only to the NGOs themselves, but also to the students of IMC FMC TBU bachelor's programs in order to find out a possible change in their perception of regional NGOs, their approach to possible cooperation, or future profiling on non-commercial marketing activities. One of the questions of the questionnaire survey focused on the preference of key competencies, which in their view, are necessary for working in the non-profit sector, in comparison with the outlook of NGOs of the ZR. The research was attended by 120 (A) students in 2017, 102 (B) in 2018 (B) and 114 (C) in 2019. The number of NGOs participating in the research decreased from the $232 \mathrm{NGO}$ in the ZR in 2017 to the 168 NGO in the ZR in 2019.

\section{Results and Interpretation}

\section{Key Competencies and the Non-profit Sector}

The current state of professional preparedness of university graduates is increasingly becoming the subject of numerous discussions. The view of company representatives on the preparedness of graduates of Czech universities is rather critical, and it does not relate to the acquired quantity of knowledge, but primarily to the ability to apply theory into practice. Many surveys focus their attention on identifying employers' requirements for key competencies of university graduates, but unilaterally only in the commercial sphere. This paper agrees with the opinion that "deficiencies appear primarily in the lack of efforts to constantly learn, think critically, cooperate and also take responsibility, but at the same time, it is in the absence of soft skills falling within the field of behavior" (NOVINKY.cz, 2018). However, what about the requirements of the representatives of the non-profit sphere, as well as university students themselves? Can a match be found here or not?

Table 4: Preferences of the key competencies of the UMC Zlin students

\begin{tabular}{|c|c|c|c|c|c|c|}
\hline \multirow[b]{2}{*}{$\begin{array}{l}\text { Key } \\
\text { competencies/preference }\end{array}$} & \multicolumn{2}{|c|}{2017 (A) } & \multicolumn{2}{|c|}{2018 (B) } & \multicolumn{2}{|c|}{$2019(C)$} \\
\hline & $\%$ & $\begin{array}{l}\text { rantin } \\
\mathrm{g}\end{array}$ & $\%$ & ranting & $\%$ & ranting \\
\hline Communication skills & $\begin{array}{c}77 . \\
5\end{array}$ & 1 & $\begin{array}{l}80 . \\
4\end{array}$ & 1 & 66.7 & 1 \\
\hline Capability of problem-solving & $\begin{array}{c}55 . \\
0\end{array}$ & 2 & $\begin{array}{l}54 . \\
9\end{array}$ & 2 & 54.4 & 3 \\
\hline Team working skills & $\begin{array}{c}37 . \\
5\end{array}$ & 3 & $\begin{array}{l}52 . \\
9\end{array}$ & 3 & 55.2 & 2 \\
\hline Taking responsibility & $\begin{array}{l}30 . \\
0\end{array}$ & 4 & $\begin{array}{c}37 . \\
3\end{array}$ & 4 & 47.4 & 4 \\
\hline $\begin{array}{l}\text { Mastering information } \\
\text { processing }\end{array}$ & $\begin{array}{c}22 . \\
5\end{array}$ & $5 / 6$ & $\begin{array}{c}12 . \\
8\end{array}$ & 7 & 11.5 & 8 \\
\hline Adaptability and flexibility & $\begin{array}{c}22 . \\
5\end{array}$ & $5 / 6$ & $\begin{array}{c}24 . \\
5\end{array}$ & 5 & 24.6 & 6 \\
\hline Willingness to learn & $\begin{array}{c}12 . \\
5\end{array}$ & $7 / 8$ & $\begin{array}{l}14 \\
7\end{array}$ & 6 & 29.8 & 5 \\
\hline
\end{tabular}

Marcela GÖTTLICHOVÁ (2020), Journal of Eastern Europe Research in Business and Economics, DOI: $10.5171 / 2020.543568$ 


\begin{tabular}{|l|c|c|c|c|c|c|}
\hline Ability to make decisions & $\begin{array}{c}12 . \\
5\end{array}$ & $7 / 8$ & 7.8 & 8 & 15.8 & 7 \\
\hline $\begin{array}{l}\text { Reading and comprehension } \\
\text { of work instructions }\end{array}$ & 7.5 & 9 & 2.9 & 10 & 10.5 & 9 \\
\hline Leadership skills & 2.5 & 10 & 6.9 & 9 & 4.9 & 10 \\
\hline
\end{tabular}

(Source: Göttlichová)

As the results of the quantitative research have shown (Table 4), there was no significant change in the preferences of the three most beneficial key competencies; acquired or consolidated, in continuity with NGO activities from the perspective of marketing communications students over the past three years. The communication skills (A/77.5\%; B/80.4\%; and C/66.7\%) are in the first place, which reflects the composition of the courses at the Institute, such as Spoken Culture, Czech Language and Stylistics, Rhetoric, Communication Theory, PR and others. The same applies to the following competencies, such as the ability to manage problems (A/55.0\%; $\mathrm{B} / 54.9 \%$; and $\mathrm{C} / 54.4 \%$ ), and to work in a team (A/37.5\%; B/52.9\%; and C/55.2\%), although their order of preference has changed over the past year, raising awareness of the importance of teamwork. These are subjects, such as Teamwork, NGO Projects, and Communication Agency, which contribute to strengthening the given competencies. Also, the fourth position in taking responsibility $(\mathrm{A} / 30.0 \%$; $\mathrm{B} / 37.3 \%$; and $\mathrm{C} / 47.4 \%$ ) demonstrates the growing positive attitude of students, and corresponds to the NGOs needs and the perception of their mission by students of the Institute. Another beneficial finding is that willingness to learn (C/29.8\%/5), and adaptability and flexibility (C/24.6\%/6) come to the fore. The lowest percentage (1$2 \%$ ) and ranking among the 11th-13th places of students in all three years rated the competencies of IT skills, foreign language knowledge, and work with numbers and figures in the working process, which, although being at the forefront of the commercial requirements, students do not consider them within the scope of NGOs mission as pivotal, or perceive them at present as a sure thing. The preferences of the first three competencies fully correspond to the requirements of the NGO in the ZR (C: $1 / 70.8 \% ; 2 / 68.8 \%$; $3 / 64.6 \%$; $4 / 58.4 \%$ ). In terms of the perception of the most common shortcomings in entering the labor market, students reported the first three positions: bearing responsibility (C/49.1\%), problemsolving $(\mathrm{C} / 43.6 \%)$ and decision-making $(\mathrm{C} / 32.7 \%)$. In terms of competencies in which students excel themselves, the following competencies ranked in the forefront: willingness to learn (C/57.7\%), teamwork (C/38.3\%), and communication skills $(\mathrm{C} / 36.4 \%)$. On the contrary, the following competencies are considered problematic: work with numbers and figures in the working process (C/54.6\%), leadership skills (C/48.2\%), and the ability to make decisions (C/37.3\%). Similarly, NGOs declared that at present they perceive the significant shortcomings to be the preparedness of graduates: the ability to take responsibility (40.2\%), the ability to make decisions (37.4\%), and the capability of problem-solving (28.1\%).

In spite of the fact that from a professional point of view, students do not see any substantial difference in the preferences of the commercial or non-commercial spheres, "since it is both the commercial as well as the non-commercial sphere that are in need of a competent", they see a significant difference in the non-commercial spheres where "a person needs to be highly motivated and more independent; people should resonate with the issue; and there is a necessity for personal values such as morality, empathy, listening ability, willingness, enthusiasm, and so on". They see NGOs from the perspective of "the increasing sense of belonging to the particular municipality, place or region"; "the entities raising citizens' sense of responsibility for themselves and their surroundings" and; "strengthening cohesion, togetherness, reconciliation and discussion inside a community". At present, $49 \%$ of students cooperate with NGOs, the other $65 \%$ stated their interest in cooperation, especially in marketing and promotion. The same percentage was confirmed by NGO in ZR, where the primary 
interest is directed to the request for assistance with promotion in the preparation and implementation of projects leading to innovation of current forms of marketing and promotion (76.5\%), followed by the preference of regular internships (48.2\%), and submission of necessary analyses in the form of bachelor and master theses (36.8\%).

\section{Conclusion}

As the resulting outcomes of the quantitative research have shown in continuity with subsequent discussions with students and representatives of the NGOs in the ZR, as well as setting the primary requirements of the "Strategic Plan of Implementation of the Long-term Plan for Educational, Scientific, Research, Development and Innovation, Art and Other Creative Activities for Higher Education in 2020", an essential step towards strengthening and enhancing the quality of higher education is in the key competencies that, for employers, whether commercial or non-commercial, will increase the employability of university graduates. The IMC FMC TBU has chosen several possibilities, such as cooperation in the form of student internships, PR consultancy, development of communication strategies for NGOs, development of creative concepts for international charity projects, or participation in the organization of the Talent MC project in collaboration with major commercial entities to bring students closer to the real-life business practice to offer creative marketing solutions based on student studies, which "becomes a great challenge for students and business representatives as a source of inspiration, new energy, and, last but not least, talented trainees, which creates the ground for networking and for short- and long-term working relationships" (TMC, 2019). "Tertiary education thus becomes an important economic factor (Juř́iková et al., 2018)."

One of the ways that reflects the requirements of the academic sphere (MEYS), non-commercial sphere (NGO) and students themselves (IMC FMC UTB), is the realization of a course named Projects of
Nonprofit Organizations, which has already been helping to solve regionally relevant topics and challenges for fifteen years, allowing the results of student projects in practice to contribute to the solution of local problems within the ZR. The Projects of Nonprofit Organizations, as a purely practical subject, allows students to apply their theoretical knowledge into practice, especially in the field of project management and marketing communications. Most of the projects proposed and realized in continuity with the knowledge of the real environment of NGOs result in the cooperation of managers with selected organizations reflected in the proposals of communication strategies, or directly in the positions of marketing experts, whether in external positions or in the future employees specializing in noncommercial marketing communications (Göttlichová, 2019).

It is a way to eliminate the mismatch of study of the requirements of potential future employers, enabling students to engage in practice, giving them the opportunity to touch on real problems and, teaching them to act, work in teams, support critical thinking skills, and develop communication and presentation skills to make university graduates significant players in the labor market in the Czech Republic, i.e., the potential advantage, not the problem.

\section{References}

- Absolventi nejsou mnohdy připraveni vstoupit na trh práce, tvrdí personalisté. 11.04.2018. NOVINKY.cz. [Online]. [Retrieved August 12, 2019]. https://www.novinky.cz/kariera/clan ek/absolventi-nejsou-mnohdypripraveni-vstoupit-na-trh-pracetvrdi-personaliste-10999.

- Balcar, J. (2006), Lidský kapitál a jeho evoluce $v$ ekonomické teorii. Ekonomická revue 9/3, s. 86-98. TU Ostrava. [Online]. [Retrieved October 10 , 2019]. https://dspace.vsb.cz/handle/10084/ 59644. 
- Dlouhodobý záměr pro oblast vysokých škol 2020 (Long-term Intention 2020). MEYS 2019. [Online]. [Retrieved August 12 , 2019]. http://www.msmt.cz/vzdelavani/vyso ke-skolstvi/plan-realizacedlouhodobeho-zameru-pro-oblastvysokych-skol-2.

- Education and training: Employment rates of recent graduates. April 2019. Eurostat/C3. [Online]. [Retrieved August 22, 2019]. https://ec.europa.eu/eurostat/statistic s-explained/.

- Education and training: Employment rates of recent graduates. April 2019. Eurostat/D52. [Online]. [Retrieved August 22, 2019]. https://ec.europa.eu/eurostat/statistic s-explained/.

- Europe 2020 education indicators in 2018. (April 26, 2019), EUROSTAT 72/2019. [Online]. [Retrieved July 18, 2019].

ttps://ec.europa.eu/eurostat/documen ts/2995521/9751510/3-26042019AP-EN.pdf.

- Hedvičáková, M. (2018), "Unemployment and effects of the first work experience of university graduates on their idea of a job," Applied Economics, Taylor \& Francis Journals, vol. 50(31), pages 3357-3363. [Online]. [Retrieved October 10, 2019]. https://doi.org/10.1080/00036846.20 17.1420895 .

- Gontkovičová, B. et al. (2015), Youth Unemployment - Current Trend in the Labor Market? Procedia Economics and Finance 23, pages 1680-1685. Conference: 2nd GLOBAL CONFERENCE On BUSINESS, ECONOMICS, MANAGEMENT and TOURISM, At Prague, Czech Republic, Volume: 23. [Online]. [Retrieved October 10, 2019]. DOI: 10.1016/S2212-5671(15)00554-7.

- Göttlichová, M. (2012), Kooperace vysokého školství, veřejné správy, podnikatelského a neziskového sektoru pro socioekonomický rozvoj regionu garantka projektu. Zlin: UTB.

- Göttlichová M. (2019), Proceedings of non-profit projects. Zlin: DigiTisk.

- Horáková, práce M., Horák, P. (2013), Zaměstnatelnostskupinohroženýchnez aměstnanostínasoučasnýchtrzích.

Sociológia 45/ 2. [Online]. [Retrieved October 16, 2019]. https://www.researchgate.net/publica tion/269989636_Zamestnatelnost_sku pin_ohrozenych_nezamestnanosti_na_s oucasnych_trzich_prace.

- Jírová, H. (2002), Situace na trhu práce v České republice. In: Spěváček, V. a kol. Transformace české ekonomiky. Praha: Linde nakladatelství, s.r.o.

- Jurečka, V. a kol. (2010), Mikroekonomie. Praha: Grada Publishing, a.s.

- Kuchař, P. (2007), Trh práce: Sociologická analýza. Praha: Karolinum.

- Monitoring indicators. Juni 2019. The Ministry of Education, Youth and Sports (MI-MEYS). [Online]. [Retrieved August 22, 2019]. http://www.msmt.cz/vzdelavani/vyso ke-skolstvi/monitorovaci-ukazatele $=1$.

- Novák, V. et al. (2016), INSTITUTIONAL ANALYSIS OF THE CONTEMPORARY REGIONAL LABOUR MARKET IN THE CZECH REPUBLIC. Economics XIX/3. [Online]. [Retrieved October 10, 2019]. https://otik.uk.zcu.cz/bitstream/1102 5/22052/1/Novak.pdf.

- VŠ - absolventi v typu studijního programu - podle věku. 21.01.2019. MŠMT-VŠ (MEYS-UG). [Online]. [Retrieved August 22, 2019]. http://www.msmt.cz/vzdelavani/vyso ke-skolstvi.

- Vzdělávání a odborná příprava 2020 (ET 2020). (2019). MEYS. [Online]. [Retrieved August 28, 2019]. 
http://www.msmt.cz/vzdelavani/vyso ke-skolstvi/et-2020.

- Talent marketingových komunikací (TMK). (2019). [Online]. [Retrieved August 12, 2019]. http://talentmk.cz/.

- The statistics of the number of nonprofit organizations in 2017- 2018. (2019). Czech Statistical Office (CZSONGOs). [Online]. [Retrieved August 12, 2019]. https://www.czso.cz/.
- $\quad$ Trh práce - časové řady. 31. 7. 2019. ČSÚ-TP (CZSO-LM). [Online]. [Retrieved July 24, 2019]. https://www.czso.cz/csu/czso/trhprace-v-cr-casove-rady-1993-2018.

- Zlínský kraj - věk a vzdělání nezaměstnaných. 2019. ČSÚ-ZK (CZSOZR). [Online]. [Retrieved July 24, 2019]. https://www.czso.cz/documents/. 